\title{
Kvantitativní a kvalitativní rozměr výzkumu postojů učitelů ve vztahu k sociálnímu znevýhodnění žáků
}

\author{
Quantitative and qualitative dimension of research of attitudes of teachers in relation to \\ social disadvantage of pupils
}

Anna Šafránková, Vladimíra Kocourková

\begin{abstract}
Abstrakt: Příspěvek se zamýšlí nad problematikou výzkumu postojů učitelů - možnostmi, ale také obtížemi, se kterými se výzkumník může setkat. Konkrétně je pak situace přiblížena na prŕípadě dílčí části realizovaného výzkumného šetření v rámci projektu IGA Analýza postojů a potřeb učitelů základnich škol ve vztahu k edukaci sociálně znevýhodněných žákü. Díky tomu, že postoj je velmi subtilní a obtížně postižitelná proměnná, zaměřujeme se a zdůrazňujeme $\mathrm{v}$ příspěvku především možnost propojení některých kvantitativních a kvalitativních výzkumných strategií. Domníváme se, že právě kombinací kvantitativních a kvalitativních metod může být zajištěna komplementarita $\mathrm{v}$ rámci zkoumané problematiky.
\end{abstract}

Klíčová slova: postoje učitelů, dotazník, postojové škály, Sémantický diferenciál, rozhovor, pozorování, obtíže ve výzkumu, sociálně znevýhodnění žáci

\begin{abstract}
This contribution is considering research issues of teachers attitudes - considering possibilities, but also the difficulties with which the researcher may will encounter. Specifically, the situation is then focused on the case of sub-section of realized research in project IGA Analysis of the attitudes and needs of primary teachers in relation to the education of socially disadvantaged pupils. In the contribution we are focusing on and emphasizing mainly the possibility of the connecting some quantitative and qualitative research strategies, because of attitude is the indefinable variable. We believe that the combination of quantitative and qualitative methods can provide complementary of the researched issues.
\end{abstract}

Keywords: attitudes of teachers, questionnaire, attitude scales, semantic differential, interview, observation, difficulties in research, socially disadvantaged pupils

V následujícím příspěvku bychom se rády zamyslely nad problematikou výzkumu postojů učitelů, nad možnostmi ale i omezeními, která s sebou tato oblast pedagogického výzkumu přináší. Oblasti výzkumu postojů se v současné době věnujeme v dílčí části výzkumného šetření v rámci projektu IGA č. projektu PdF_2011_035 Analýza postojů a potřeb učiteli̊ základních škol ve vztahu $k$ edukaci sociálně znevýhodněných žáků. Toto výzkumné šetření je zaměřeno konkrétně na postoje učitelů ve vztahu k sociálně znevýhodněným žákům, respektive obecně $\mathrm{k}$ sociálnímu znevýhodnění žáka, ale i jeho rodiny. Zaměřujeme se na skupinu učitelů škol na úrovni ISCED 1 a 2 v České republice, konkrétně v Pardubickém a Moravskoslezském kraji.

První výzkumy postojů byly realizovány již počátkem 20. století v USA a postupně se díky svému specifickému charakteru těmito výzkumy zabývaly nejenom výzkumy voblasti sociologie, sociální psychologie (Ajzen, 2005), ale také se implementovaly do pedagogických 
výzkumů. Postoj můžeme vymezit např. podle J. Čápa a J. Mareše (2001) jako získaný motiv vyjadřující jedincův vztah k určitému objektu, k věci, lidem, činnosti, skupině, události, ideji apod. Obdobně vymezuje postoj R. L. Atkinsonová a kol. (1995). P. Hartl (psychologický slovník) (1993) definuje postoj jako sklon reagovat ustáleným způsobem na předměty, osoby, situace, nebo na sebe sama.

Vývoj tohoto pojmu shrnuje M. Nakonečný (1997), který uvádí, že tento pojem zavedli do sociologie a psychologie W. J. Thomas a F. Znaniecki (1918), kteří jej chápali jako vědomí vztah jedince k hodnotě (in Nakonečný, 1997, s. 217). Klasickou definici podal G. W. Allport (1935) který uvádí, že postoj je mentální a nervový vztah pohotovosti, organizovaný zkušeností a vyvíjející direktivní nebo dynamický vliv na odpovědi individua vůči všem objektům a situacím, s nimiž je v relaci. Postoj učitele můžeme v souladu s uvedeným vymezit jako motiv vyjadřující učitelův vztah k žákovi, ke skupině žáků, ke školnímu prostředí a v obecné rovině přímo ke školní edukaci a vlastní profesi. Naše výzkumné šetření je zaměřeno na učitelův vztah k žákovi pocházejícímu ze sociálně znevýhodněného prostředí, k rodičům tohoto žáka a sociálnímu znevýhodnění obecně. Vychází z předpokladu, že bez důkladné znalosti postojů učitelů $\mathrm{k}$ sociálně znevýhodněným žákům, kdy postoje chápeme jako heterogenní komplex hodnocení, cítění a tendence konání, není možno složitou a mnohodimenzionální problematiku edukace sociálně znevýhodněných žáků nejen chápat, ale ani úspěšně ovlivňovat a řídit. Pro účely uváděného výzkumu chápeme sociálně znevýhodněného žáka $\mathrm{v}$ souladu $\mathrm{s}$ Rámcovým vzdělávacím programem pro základní vzdělávání jako jedince, který pochází z prostředí sociálně nebo kulturně a jazykově odlišného od prostředí, v němž vyrůstají žáci pocházející z majoritní populace.

Výzkumem postojů obecně se zabývala a zabývá řada výzkumníků, úzce specifikované výzkumy na postoje učitele k žákům jsou zastoupeny v menší míře (např. Potměšil, 2010), výzkumy postojů učitele $\mathrm{k}$ žákům se sociálním znevýhodněním jsou v českém prostředí spíše ojedinělé. Na základě některých realizovaných výzkumných šetření (např̀. Helus \& Pelikán, 1984) lze předpokládat, že učitelův postoj může působit na samotnou edukační činnost žáka, proto vnímáme realizaci těchto výzkumných šetření i v současnosti jako velmi aktuální. Tento výzkum s sebou však nese určitá úskalí, na která by měl být výzkumník připraven.

Především si musíme uvědomit, co postoj opravdu je. Výše jsme uvedly definici, která však nevystihuje okolnosti vzniku a vlastnosti postojů. Zde máme na mysli zejména skutečnost, že postoj jedince se vyvíjí a to, co zjistíme, odpovídá pouze danému okamžiku. O dalších problémových oblastech, které mohou hrát ve vztahu k námi diskutovanému výzkumu postojů učitelů významnou roli, uvažuje M. Vávra (2006). Jednak jde o zajištění, aby respondenti brali výzkum skutečně vážně (eliminace náhodných odpovědí) a dále problém střetu postojů. $\mathrm{V}$ prvním př́padě můžeme narazit i na problém, kdy mohou učitelé $\mathrm{z}$ různých důvodů (pracovní vytížení, nedostatek motivace, nedostatečný respekt k problému) výzkum zcela odmítnout, nebo, jak uvádí Vávra, mohou být získané informace vlivem náhodných odpovědí zkreslené. Zkreslení může nastat i vlivem vžití se respondenta do určité role, kdy odpovídá podle toho, co předpokládá, že se očekává. Druhý př́ípad ukazuje na skutečnost, že může dojít ke střetu postojů a to postoje $\mathrm{k}$ objektu a postoje $\mathrm{k}$ situaci ( $\mathrm{v}$ našem př́ípadě $\mathrm{k}$ profesi). To znamená, že i za situace, kdy by měl učitel negativní postoj ke skupině sociálně znevýhodněných žáků plynoucí např. z negativní zkušenosti, může u něj převládnout profesionalita tedy postoj $\mathrm{k}$ profesi a tento negativní postoj $\mathrm{k}$ sociálně znevýhodněným žákům se neprojeví. Velmi obtížně budeme zachycovat míru profesionality daného jedince. Nelze také zaručit, že i v př́ípadě profesionálního prŕístupu se zejména v neuvědomovaných situacích neprojeví původní negativní postoj.

Úskalí s sebou mohou dále přinášet i jednotlivé výzkumné metody a nástroje, respektive způsob jejich užití. Rády bychom se proto nyní podrobněji zastavily u vybraných, podle 
našeho názoru nejčastěji používaných nástrojů měření postojů, jejich přínosu a možných úskalí jejich užití.

Jako jedna z významných metod pro výzkum postojů se použivá Osgoodova metoda Sémantického diferenciálu. Tato metoda zjištuje individuální význam klíčových pojmů a jejich významovou blízkost (Osgood et al., 1975). Metoda Sémantického diferenciálu je charakteristická spojením psycholingvistiky, psychologie vnímání a psychologie individuálního vědomí (Maršálová, Mikšík et al., 1990). Osgood vycházel z předpokladu, že pro jedince určitý objekt skrývá jak denotativní význam, tak konativní význam, jež lze vyjádřit jako bod tzv. sémantického prostoru (Osgood et. al., 1975). Metoda Sémantického diferenciálu je založena na tom, že respondenti zaznamenávají svoje mínění o posuzovaných pojmech na několikabodových škálách, jež jsou tvořeny protikladnými adjektivy (Chráska, 2007). U každého pojmu jsou obvykle sledovány tři faktory - faktor hodnocení, faktor potence a faktor aktivity, jež tvoří trojdimenzionální sémantický prostor (Chráska, 2007). Možné úskalí této metody podle nás spočívá $\mathrm{v}$ jejím zadání a následném vyhodnocení. Záleží na tom, zda se výzkumník táže opravdu na postoj jedince $\mathrm{k}$ danému pojmu, nebo zda se ptá na postoj $\mathrm{k}$ dané věci/osobě, kterou pojem vyjadřuje. (Např́iklad. osoba trvale bez přistřeší, bezdomovec předpoklad odlišné konotace). Metoda Sémantického diferenciálu podle nás zjišt'uje pouze dílčí část emotivní složky postoje jedince, důležité je vhodné zvolení klíčových pojmů.

Další rovinu ve výzkumu postojů učitelů k sociálnímu znevýhodnění nám mohou odkrýt také postojové škály, na jejichž základě lze stanovit intenzitu positivního či negativního afektu. Škály se skládají z určitého počtu výroků, se kterými respondent více či méně souhlasí či nesouhlasí. Postojové škály také implikují neutrální postoj, jenž je umístěn mezi protipóly souhlasu a nesouhlasu (Černoušková, 1988). Díky srozumitelnému formulování jednoduchých výroků zaměřených na problematiku sociálního znevýhodnění zjišt’ujeme, v jakém stupni respondent výrok přijímá či odmítá. U škál se potýkáme s problémem dilematu sudých a lichých voleb možností. Výzkumník si musí dát pozor také na vhodné formulace výroků, které bude respondent posuzovat. Škály mají na rozdíl od Sémantického diferenciálu nižší úroveň latentního významu, hrozí tedy vyšší riziko, že se může respondent projektovat do určité role.

Měření postojů je celkově značně komplikované, nebot' se jedná o multidimenzionální subtilní proměnnou (Chráska, 2007). Kognitivní složku postojů v našem výzkumu můžeme zachytit pomocí dotazníku. Dotazníkovým šetřením, jakožto nejfrekventovanější metodě získávání dat (Gavora, 2000), mapujeme především vědomosti a zkušenosti učitelů ve vztahu k sociálnímu znevýhodnění žáků. Vedle nízkých nákladů na sběr a jejich vyhodnocení, možnosti oslovení širokého spektra respondenti̊. Oppenheim (1992) spatřuje hlavní výhody dotazníkové metody zamezení zkreslení, ke kterému může dojít při osobnímu rozhovoru. Naopak hlavní nevýhody této metody shledává především v návratnosti dotazníků a ve skutečnosti, že všichni respondenti nemusí pochopit, na co jsou dotazováni.

Mezi další metody, které je možno při výzkumu postojů použít patří rozhovor a pozorování. Obě tyto metody mohou při využití kvalitativní strategie přispět $\mathrm{k}$ hlubší analýze postojů. Rozhovor, zejména nestrukturovaný, může do výzkumu přinést nové informace jak o kognitivní, tak o emotivní postojové složce. Pozorování nám může poskytnout významné informace o konativní složce postoje. Obě tyto metody předpokládají dokonalou př́ípravu ze strany výzkumníka. V obou př́padech se jedná o metody, které jsou na rozdíl od předchozích časově náročnější, snad i proto bývají ve výzkumech postojů méně využívané. Domníváme se však, že jejich prínos je nenahraditelný.

Shrneme-li výše uvedené, domníváme se, že jednotlivými výzkumnými metodami zjišt’ujeme pouze dílčí aspekty postojů. Postoj se skládá kognitivní, emotivní a konativní složky, abychom jej dokázali co nejpřesněji zachytit, potřebujeme znát informace o všech těchto třech 
složkách. Předpokládáme proto, že komplexním uchopením problematiky za využití metodické triangulace a při kombinaci kvalitativních a kvantitativních metod můžeme nalézt přesnější obraz reality. Podle našeho názoru by mohl být vhodný model qaul - quan - qual.

V našem výzkumném šetření jsme na základě daných podmínek (zejména omezení časové a finanční) zvolili kombinaci metod dotazníku, Sémantického diferenciálu a postojové škály. Tvorbě výzkumného nástroje předcházelo několik konzultací s učiteli primárních škol a pracovníky pedagogicko - psychologických poraden, díky nimž jsme mohly zoptimalizovat výzkumné položky. Výzkumný nástroj zahrnuje 30 dotazníkových položek, v rámci nichž se objevují strukturované, polostrukturované i nestrukturované položky, ve kterých se učitelé mohou libovolně vyjádřit $\mathrm{k}$ danému tématu. Dále obsahuje 32 výroků v rámci postojových škál, jejichž koncipování bylo inspirováno Likertovými analýzami (Likert et. al., 1934). Třetí část vytvořeného výzkumného nástroje tvoří metoda Sémantického diferenciálu, jejíž užití je sice náročné, ale může přinést hodnotné výsledky, nebot' analyzuje sémantickou podstatu jedince ve vztahu k sociálnímu znevýhodnění.

V současné době probíhá vyhodnocení výsledků předvýzkumu. Samotný výzkum plánuje získat vzorek 300 respondentů. Jsme si vědomy toho, že výzkum ve svém rozsahu nemůže postihnout celou problematiku postojů učitelů $\mathrm{k}$ fenoménu sociálního znevýhodnění, nicméně se domníváme, že alespoň dílčí část mapující postoje učitelů zahrnující předsudky, zkušenost, mínění, přesvědčení apod. může pomoci zachytit tuto velmi subtilní determinantu $\mathrm{v}$ oblasti inkluzivního vzdělávání sociálně znevýhodněných žáků a obecně pedagogického procesu. Získaná data se mohou stát námětem a zdrojem pro výzkumná šetření širšího rozměru a následně i šetření zaměřená prrímo na ověrení vlivu zjištěných postojů na edukační proces.

\section{Literatura}

Allport, G., W. (1935). Attitudes. In C. Murchison (Ed.), Handbook of social psychology. Worcester, Mass: Clark University Press.

Ajzen, I. (2005). Attitudes, personality and behavior. Maidenhead: Open University Press.

Atkinsonová, L. R. a kol. (1995). Psychologie. Praha: Victoria Publishing

Čáp, J., \& Mareš, J. (2007). Psychologie pro učitele. Praha: Portál.

Černoušková, V. (1988). Sociální postoje a možnost jejich měřní v pedagogické praxi. Olomouc.

Gavora, P. (2000). Úvod do pedagogického výzkumu. Brno: Paido.

Hartl, P. (1993). Psychologický slovnik. Praha: Budka.

Helus, Z., \& Pelikán, J. (1984). Preferenční postoje učitelů $k$ žákům a jejich vliv na účinnost výchovně vzdèlávacího procesu. Praha: Výzkumný ústav odborného školství.

Chráska, M. (2007). Metody pedagogického výzkumu. Praha: Grada.

Jeřábek, J., et. al. (2005) Rámcový vzdělávaci program pro základni vzdělávání: s př́lohou upravujici vzdělávání žáku s lehkým mentálním postižením. Praha: VÚP v Praze.

Likert, R., Roslow, S., \& Murphy H. (1934). A simple and reliable method of scoring the Thurstone attitude scales. J. soc. Psychol., 5, 228-338.

Maršálová, L., \& Mikšík, O. et al. (1990). Metodológia a metody psychologického výskumu. Bratislava: SPN.

Nakonečný, M. (1997). Encyklopedie obecné psychologie. Praha: Academia.

Oppenheim, A. N. (1992). Questionnaire design, interviewing and attitude measurement. London: Continuum.

Osgood, CH. E., Suci, G. J., \& Tannenbaum, P. H. (1975). The measurement of meaning. Urbana: University of Illinois.

Potměšil, M. (2010). Inkluzivní vzdělávání v primárni škole = Inclusive education in primary school. Brno: Paido.

Vávra, M. (2006). Nesnáze s měřením postojů. SDA info, 7(1), 9-12. 


\section{Kontakt}

Mgr. Anna Šafránková

PhDr. Vladimíra Kocourková, Ph.D.

Univerzita Palackého v Olomouci

Pedagogická fakulta, Ústav pedagogiky a sociálních studií

Žižkovo nám. 5, 77140 Olomouc

e-mail: anna.safrankova01@upol.cz

vladimira.kocourkova@upol.cz

\section{Bibliografické údaje}

Šafránková, A., \& Kocourková, V. (2011). Kvantitativní a kvalitativní rozměr výzkumu postojů učitelů ve vztahu k sociálnímu znevýhodnění žáků. In T. Janík, P. Knecht, \& S. Šebestová (Eds.), Smišený design v pedagogickém výzkumu: Sborník př́spěvků z 19. výroční konference České asociace pedagogického výzkumu (s. 416-420). Brno: Masarykova univerzita.

Dostupné z: http://www.ped.muni.cz/capv2011/sbornikprispevku/safrankovakocourkova.pdf doi: 10.5817/PdF.P210-CAPV-2012-53 